\title{
Fertilizer Adoption Impact on Maize Yield Growth: Disparity among Major Maize Growing Administrative Regions of Ethiopia
}

\author{
Fitsum Daniel \\ Ethiopian Institute of Agricultural Research, Addis Ababa, Ethiopia
}

\begin{abstract}
This study examines the regional disparity in the impact of adoption of fertilizer (organic, inorganic or both) on yield growth using 953 sample farm households in five major maize growing administrative regions of Ethiopia. Propensity score matching (PSM) technique was employed since it is an increasingly utilized standard approach for evaluating impacts using observational data. It is found that adoption of fertilizer doesn't have homogenous positive and significant impact on yield growth in all of the administrative regions considered. Thus, the study recommends that the agricultural research and extension system of the country should further consider the various differences that exist among different regions and areas of the country so as to generate and disseminate suitable improved agricultural technologies and information.
\end{abstract}

Keywords: Impact, Maize, Fertilizer, Ethiopia

DOI: $10.7176 / \mathrm{JESD} / 11-19-05$

Publication date:June 30th 2020

\section{Introduction}

As it is well known, agriculture is the mainstay of the Ethiopian economy. The sector constitutes over $47 \%$ of the gross domestic product (GDP), accounts for about $75 \%$ of the labor force and earns over $90 \%$ of the foreign exchange (Dorosh and Rashid, 2012; Welteji, 2018 citing Alemu et al., 2010). According to the national accounts, the agricultural sector consists of crop, livestock, fishery and forestry sub-sectors (Bekabil, 2018). As to Welteji 2018 , crop production on average makes up $60 \%$ of the sector's outputs, whereas livestock accounts for $27 \%$ and other areas contribute $13 \%$ of the total agricultural value added. On the other hand, cereals dominate Ethiopian crop production (Dorosh and Rashid, 2012). Accordingly citing CSA 1998, CSA 2001, CSA 2003 and CSA 2007 data, it accounts for roughly 60 percent of rural employment, about 73 percent of total cultivated land, more than 40 percent of a typical household's food expenditure, and more than 60 percent of total calorie intake. Moreover, cereals' contribution to agricultural value-added is 65 percent, which translates to about 30 percent of gross domestic product (GDP) (Dorosh and Rashid, 2012). Thus, a closer look at what is happening in cereal production has an important welfare and policy implication in Ethiopia (Abegaz, 2011).

According to Kelemu 2017 citing FAO 2014, maize is the first most important food in the country in terms of caloric intake. According to Jaleta et al. 2015 citing CSA 2014b, on average, $76 \%$ of maize produced is consumed at home and no other cereal crop produced reaches to this level in terms of retention for home consumption. At present, as a sub-Saharan country, Ethiopia has the fifth largest area devoted to maize but is second, only to South Africa, in yield and third, after South Africa and Nigeria, in production (Abate et al., 2015). In Ethiopia, maize ranks first in volume of production and second in total allocation to production area. Maize is the second most widely cultivated crop in Ethiopia and is grown under diverse agro-ecologies and socioeconomic conditions typically under rain-fed production (Abate et al., 2015). It is adapted to and grown in diverse agroecologies starting from mid-lowlands to highlands of the country except in both extreme lowlands and highlands (Jaleta et al., 2015). Moreover, according to Abate et al. 2015 citing CSA 2011-13 data, more than 9 million households, more than for any other crop, grow maize in Ethiopia. Accordingly, the annual rate of growth for the number of households cultivating maize grew at $3.5 \%$ each year between 2004 and 2013 , compared to $3.0 \%$ for sorghum, $3.1 \%$ for teff, $2.1 \%$ for wheat, and $1.8 \%$ for barley. Largely because of the increasing demand driven by population growth and competitiveness of the crop, maize area in Ethiopia doubled during the past two decades from 1 to 2 million hectares and the growth in the proportion of maize area was higher than all other major cereals over the last three decades (Abate et al., 2015 citing Rosegrant et al., 2001).

The Ethiopian agricultural sector is dominated by small-scale farmers who practice rain-fed mixed farming by employing traditional technology, adopting a low-input and low-output production system (Welteji, 2018 citing Gebreselassie and Bekele, 2010). Accordingly, the land tilled by the Ethiopian small-scale farmer accounts for $95 \%$ of the total area under agricultural use, and these farmers are responsible for more than $90 \%$ of the total agricultural output. Furthermore, most smallholder farms are located in the moisture-reliable cereal-based highlands, which accounts for 59 percent of all farm area (Dorosh and Rashid, 2012).

With respect to all these facts, it is not questionable that accelerated and sustained growth in the country's agriculture in general and in the crop sub-sector in particular with special emphasis to the small-scale farmers will greatly help to achieve the various goals of the country (Gebru, 2006; MoFED, 2003; Gebre-Selassie \& Bekele). Although a majority of production increases in the past occurred due to increases in the area cultivated, area and 
yield increases each accounted for about half of production growth in the 2000s and we thus see an initial start of increasing intensification (Bekabil, 2018; Dorosh and Rashid, 2012). Accordingly, with little suitable uncultivated land available for expansion of crop cultivation apart from pasture land, especially in the highlands, production gains in terms of yield increases are critical to meet agricultural growth goals.

In this connection, the current use of improved inputs is relatively low, suggesting that there is substantial scope for raising productivity through the increasing adoption of improved seeds and both chemical and organic fertilizers, at least in the rainfall-sufficient ecologies (and on irrigated farms) (Bekabil, 2018; Dorosh and Rashid, 2012). In this regard, as a strategic food security crop, since 1970s, international and national research centers exerted collaborative efforts in improving the genetic potential of maize and its adaptability to different agroecologies in the country (Jaleta et al., 2015). Accordingly citing MoA 2012, about 60 improved maize varieties have been released or registered in the country since the 1970s through this integrated effort. Given soil erosion due to deforestation, overgrazing, and cultivation of slopes not suited to agriculture together with the farming practice that do not include conservation measures is one of the major agricultural problems in the highlands of Ethiopia, there is a high government interest to expand the use of fertilizer that is considered by Ethiopian policy makers as a strategic input to increase cereals production (Bekabil, 2018 citing Abay, 2011).

Maize inputs in Ethiopia include mainly improved seed and fertilizers (Abate et al., 2015). However, according to Jaleta et al. 2015 citing Feleke and Zegeye 2006, Tura et al. 2010 as well as Kassa et al. 2013, the level of improved maize variety adoption by smallholder farmers is still low although a large number of maize varieties have been released. In this regard, Abate et al. 2015 using an unpublished data from Ministry of Agriculture mentioned that the share of total modern varieties used in Oromia region during 2010-12 was 49\% of the total; Amhara and South Nations Nationalities and People regions accounted for 33 and 18\%, respectively, with Benishangul-Gumuz and Tigray regions both receiving less than $1 \%$ each. They also estimated based on CSA data for 2004 to 2013 that about $23 \%$ of the total mineral fertilizer in Ethiopia is applied to maize. Accordingly, an average of $69 \%$ of all maize grown in 2013 in Ethiopia received some amount of mineral fertilizer application, compared to $56 \%$ in 2004. However, numerous farmers (as many as half in some regions) have consistently reported late delivery of fertilizer in recent years (Dorosh and Rashid, 2012). Accordingly, moreover, unlike neighboring countries such as Kenya, Ethiopia does not offer fertilizer in smaller packages that could be used by smallholders or in different formulations needed for different types of agro-climates, soils, and crops.

Even though crop productivity and production remained low and variable in the 90s for the most part, there have been clear signs of change over the past decade (Abate et al., 2015). Accordingly, national maize yields have doubled from about 1.50 MT/ha during the early 1990s to $3.23 \mathrm{MT} / \mathrm{ha}$ in 2013. On average, maize area and productivity increased by 4.0 and 6.3\% per annum, respectively, during the 10 years between 2004 and 2013 . Similarly, the annual rate of growth for production during the same period was $10.5 \%$ and it is interesting to see that the increases in maize production in Ethiopia resulted more from increases in productivity rather than area expansion (Abate et al., 2015). However, the contribution of agriculture to food security both through its direct impact on food production and indirect effect on farm incomes has failed to recover even after the economic reforms of the 1990s (Bekabil, 2018 citing Samuel, 2003). Accordingly, despite some short-lived successes in some areas and years, the impact of the country's new development strategy that is commonly known as Agricultural Development-Led Industrialization (ADLI) and its main instrument, PADETES (Participatory Demonstration and Training Extension System) was too little to affect per capita agricultural production or productivity at national level or in a sustainable manner. These all obviously calls for a further and a better growth in agricultural productivity as well as quality with minimum adverse impact on the environment mainly through the supply, duplication and diffusion of continuously improving as well as location specific technology and information.

Holistic and appropriate evaluation of the efforts and corresponding results as well as reasons/strengths and weaknesses/ of the past few decades in general and of the past recent years in particular is necessary in order to create a more fertile ground for the fast achievement of the aforementioned goal. In this regard, the role of historical data collected by different agencies like CSA as well as of different socio-economic studies carried out to provide vital policy and related recommendations is indispensable. Studies that assess the contribution of improved crop management practices information and technologies like improved crop varieties for the productivity growth of such important and widely cultivated cereals like maize in Ethiopia in the past recent years are among studies that can be cited in relation to this. However, studies carried out in the country on this issue are not only few but also restricted to piece meal or location specific approach. Besides, most studies were biased towards those locations that had high/better suitability and/or preference for the production of the specific crop considered. As a result, a nationally or regionally representative data could not be collected for the studies and the conclusions drawn so far would have low probability of influencing national and regional policies. Thus, the objective of this study is to identify the regional disparity in the impact of adoption of fertilizer (organic, inorganic or both) on maize productivity per unit of land cropped among five administrative regions of Ethiopia (namely Oromia, Amhara, South Nations, Nationalities \& People, Tigray and Benishangul-Gumuz) which are also known to be the major 
maize producing regions in the country.

\section{Materials and Methods}

\subsection{Analytical Framework for Evaluation}

An impact evaluation provides information about the impacts produced by an intervention which might be a small project, a large program, a collection of activities, or a policy. Many development agencies use the definition of impacts provided by the Organization for Economic Co-operation and Development - Development Assistance Committee: "positive and negative, primary and secondary long-term effects produced by a development intervention, directly or indirectly, intended or unintended." (OECD-DAC 2010). If an impact evaluation fails to systematically undertake causal attribution, there is a greater risk that the evaluation will produce incorrect findings and lead to incorrect decisions. Causal attribution is defined by OECD-DAC as: "Ascription of a causal link between observed (or expected to be observed) changes and a specific intervention." (OECD_DAC 2010). This definition does not require that changes are produced solely or wholly by the intervention under investigation. In other words, it takes into consideration that other causes may also have been involved, for example, other interventions in the area of interest or certain contextual factors (often referred to as 'external factors').

Inference about the impact of a treatment on the outcome of an individual involves speculation about how this individual would have performed had (s)he not received the treatment and the standard framework in evaluation analysis to formalize this problem is the potential outcome approach or Roy-Rubin model (Caliendo and Kopeinig, 2008 citing Roy, 1951 and Rubin, 1974). Accordingly, in the case of a binary treatment, the treatment indicator $D_{i}$ equals one if individual $i$ receives treatment and zero otherwise. The potential outcomes are then defined as $Y_{i}\left(D_{i}\right)$ for each individual $i$, where $i=1, \ldots, N$ and $N$ denotes the total population. The treatment effect for an individual $i$ can be written as

$\tau_{i}=Y_{i}(1)-Y_{i}(0)$

The fundamental evaluation problem arises because only one of the potential outcomes is observed for each individual $i$ where the unobserved outcome is called the counterfactual outcome, that is, what would have happened to participants in absence of treatment (Caliendo and Kopeinig, 2008; Heinrich et al., 2010). Hence, estimating the individual treatment effect $\tau_{i}$ is not possible and one has to concentrate on (population) average treatment effects.

Of fundamental interest in all evaluation efforts is whether a particular intervention, as designed, is effective in accomplishing its primary objectives (Heinrich et al., 2010). According to Caliendo and Kopeinig 2008, among the two parameters which are most frequently estimated in the literature, the first one is the population average treatment effect (ATE), which is simply the difference of the expected outcomes after participation and nonparticipation:

$\tau_{A T E}=E(\tau)=E[Y(1)-Y(0)]$

This estimate, however, might not be of relevance to policy makers because it includes the effect on persons for whom the intervention was never intended (Caliendo and Kopeinig, 2008 citing Heckman, 1997). Therefore, the most prominent evaluation parameter is the so-called average treatment effect on the treated (ATT) given by $\tau_{A T T}=E(\tau \mid D=1)=E[Y(1) \mid D=1]-E[Y(0) \mid D=1]$,

which focuses explicitly on the effects on those for whom the intervention is actually intended (Caliendo and Kopeinig, 2008). Accordingly, the expected value of ATT is defined as the difference between expected outcome values with and without treatment for those who actually participated in treatment.

As the counterfactual outcome is never observed, it has to be estimated using statistical methods. In this regard, taking the mean outcome of nonparticipants as an approximation is not advisable, since participants and nonparticipants usually differ even in the absence of treatment and this problem is known as selection bias (Caliendo and Kopeinig, 2008).

The matching approach is one possible solution to the selection problem (Caliendo and Kopeinig, 2008). Accordingly, it originated from the statistical literature and shows a close link to the experimental context. Its basic idea is to find in a large group of nonparticipants those individuals who are similar to the participants in all relevant pretreatment characteristics X. That being done, differences in outcomes of this well selected and thus adequate control group and of participants can be attributed to the intervention.

Since conditioning on all relevant covariates is limited in the case of a high dimensional vector X ('curse of dimensionality'), Rosenbaum and Rubin (1983b) as to Caliendo and Kopeinig 2008 suggest the use of so-called balancing scores $b(X)$, i.e. functions of the relevant observed covariates $\mathrm{X}$ such that the conditional distribution of $\mathrm{X}$ given $\mathrm{b}(\mathrm{X})$ is independent of assignment into treatment. One possible balancing score in this regard is the propensity score. According to Olmos 2015, propensity scores are defined as the conditional probability of assigning a unit to a particular treatment condition (i.e., likelihood of receiving treatment), given a set of observed covariates. Matching procedures based on this balancing score are known as propensity score matching (PSM).

Such matching estimator as PSM will not, however, necessarily work in all circumstances (Caliendo and Kopeinig, 2008; Heinrich et al., 2010). Accordingly, some identifying assumptions have to be met to produce valid 
impact estimates:

Assumption 1 (Conditional Independence Assumption or CIA): there is a set X of covariates, observable to the researcher, such that after controlling for these covariates, the potential outcomes are independent of the treatment status:

$\left(Y_{1}, Y_{0}\right) \perp D \mid X$

This property is also known as un-confoundedness or selection on observables.

Assumption 2 (Common Support Condition): for each value of $X$, there is a positive probability of being both treated and untreated:

$0<P(D=1 \mid X)<1$

The second requirement is also known as overlap condition, because it ensures that there is sufficient overlap in the characteristics of the treated and untreated units to find adequate matches (or a common support). When these two assumptions are satisfied, the treatment assignment is said to be strongly ignorable (Rosenbaum \& Rubin, 1983).

In fact, when the parameter of interest is the ATT, the CIA assumption can be relaxed to: $Y_{0} \perp D \mid X$ since we need only to construct the counterfactual for the treated individuals.

Given that CIA holds and assuming additionally that there is overlap between both groups, the PSM estimator for ATT can be written in general as

$\tau^{P S M_{A T T}}=E_{P(X) \mid D=1}\{E[Y(1) \mid D=1, P(X)]-E[Y(0) \mid D=0, P(X)]\}$

To put it in words, the PSM estimator is simply the mean difference in outcomes over the common support, appropriately weighted by the propensity score distribution of participants (Caliendo and Kopeinig, 2008).

In PSM, the procedure for estimating the impact of an intervention can be divided into three straightforward steps: (1) Estimate the propensity score, (2) Choose a matching algorithm that will use the estimated propensity scores to match untreated units to treated units as well as (3) Estimate the impact of the intervention with the matched sample and calculate standard errors (Heinrich et al., 2010).

For a binary treatment variable, there is no strong advantage to using the logit vs. probit model to estimate the propensity score, although both are typically preferred to a linear probability model (Heinrich et al., 2010). According to them, it is critical that a flexible functional form which allows capturing possible nonlinearities of the participation model be used and that all relevant covariates that relate to treatment status and outcomes are included in this model (to account for differences between treated and untreated units). Hence, economic theory, a sound knowledge of previous empirical findings and also information about the institutional settings should guide the researcher in building up the model (Caliendo and Kopeinig, 2008). Accordingly, it should also be clear that only variables that are unaffected by participation (or the anticipation of it) should be included in the model and to ensure this, variables should either be fixed over time or measured before participation. In the latter case, it must be guaranteed that the variable has not been influenced by the anticipation of participation. According to them, Heckman et al. (1999) also point out that the data for participants and nonparticipants should stem from the same sources (e.g. the same questionnaire). The better and more informative the data are, the easier it is to credibly justify the CIA and the matching procedure.

In choosing between different matching algorithms, the primary factors that should be considered are: (1) Matching with or without replacement, (2) How to assess for the closeness of the match, (3) Whether and how to weight cases in the analysis and (4) Number of comparison units matched to each treatment unit (Heinrich et al., 2010). According to them, in nearest neighbor matching which is among the commonly employed matching algorithms, an individual from the comparison group is chosen as a match for a treated individual in terms of the closest propensity score. On the other hand, Kernel matching is a nonparametric matching estimator that compares the outcome of each treated person to a weighted average of the outcomes of all the untreated persons, with the highest weight being placed on those with scores closest to the treated individual. Unfortunately, there is no clear rule for determining which algorithm is more appropriate in each context. However, a key issue that should be considered is that the selection of the matching algorithm implies a bias/efficiency trade-off (Heinrich et al., 2010). Pragmatically, it seems sensible to try a number of approaches. Should they give similar results, the choice may be unimportant. Should results differ, further investigation may be needed in order to reveal more about the source of the disparity (Caliendo and Kopeinig, 2008 citing Bryson et al., 2002).

As with any experimental or nonexperimental method used in impact evaluation, it is important to check the key assumptions that are made in the estimation and verify that the model specification is appropriate and that the results do not suffer from bias. Unfortunately, the conditional independence assumption is not directly testable but still requires justification like those mentioned before (Heinrich et al., 2010). According to them, checking the overlap or region of common support between treatment and comparison groups can be done with relatively straightforward strategies and one obvious approach is through visual inspection of the propensity score distributions for both the treatment and comparison groups. Simple histograms or density-distribution plots of propensity scores for the two groups, along with a comparison of the minimum and maximum propensity score values in each distribution, can typically give the researcher a good, initial reading of the extent to which there is 
overlap in the propensity scores of the treatment and comparison units (Heinrich et al., 2010).

Since we do not condition on all covariates but on the propensity score, it has to be checked if the matching procedure is able to balance the distribution of the relevant variables in both the control and treatment group (assessing the matching quality, i.e.). There are several procedures to do so and the basic idea of all is to compare the situation before and after matching and check if there remain any differences after conditioning on the propensity score (Caliendo and Kopeinig, 2008). As to them, Sianesi (2004) suggests to re-estimate the propensity score on the matched sample and compare the pseudo-R2s before and after matching. After matching there should be no systematic differences in the distribution of covariates between both groups and therefore the pseudo-R2 (which indicates how well the regressors X explain the participation probability) should be fairly low. Furthermore, one can also perform a likelihood ratio test on the joint significance of all regressors in the probit or logit model. The test should not be rejected before, and should be rejected after, matching (Caliendo and Kopeinig, 2008).

\subsection{Data and Variables}

The data utilized for this study is acquired from the third wave of the Ethiopia Socioeconomic Survey (ESS) 20152016. The Ethiopian Socioeconomic Survey (ESS) is a collaborative long-term project between the Central Statistics Agency of Ethiopia (CSA) and the World Bank Living Standards Measurement Study-Integrated Surveys on Agriculture (LSMS-ISA) team to collect panel data. The project responds to the data needs of the country, given the dependence of a high percentage of households in agriculture activities in the country. The ESS collects information on household agricultural activities along with other information on the households like human capital, other economic activities, access to services and resources. The ability to follow the same households over time makes the ESS a new and powerful tool for studying and understanding the role of agriculture in household welfare over time as it allows analyses of how households add to their human and physical capital, how education affects earnings, and the role of government policies and programs on poverty, inter alia. ESS uses a nationally representative sample of over 5,000 households living in rural and urban areas. The urban areas include both small and large towns. The sample is a two-stage probability sample. The first stage of sampling entailed selecting primary sampling units, which are a sample of the CSA enumeration areas (EAs). The second stage of sampling was the selection of households to be interviewed in each EA. A total of 433 EAs were selected based on probability proportional to size of the total EAs in each region out of which 290 were rural, 43 were small town EAs from ESS1, and 100 were EAs from major urban areas. In order to ensure sufficient sample size in the most populous regions (Amhara, Oromiya, SNNP, and Tigray) and Addis Ababa, quotas were set for the number of EAs in each region. The sample is not representative for each of the small regions including Afar, BenishangulGumuz, Dire Dawa, Gambella, Harari, and Somali regions. However, estimates can be produced for a combination of all smaller regions as one "other region" category. During wave 3, 1255 households were re-interviewed yielding a response rate of 85 percent. Attrition in urban areas is $15 \%$ due to consent refusal and inability to trace the whereabouts of sample households.

Yield stands for the yield of maize per unit of land cropped measured in quintals per hectare.

LnYield stands for the natural logarithmic transformation of Yield.

HHAGE stands for the age of a household head in years.

HHSEX is a dummy variable indicating the sex of a household head where HHSEX $=1$ if the head is male and 0 if otherwise.

HHEDU is a dummy variable indicating whether a household head is literate where HHEDU $=1$ if the head is literate/able to read and write in any language / and 0 if otherwise.

HHRELIGION is a dummy variable indicating the main religion of a household head.

FAMILY SIZE stands for size of a household.

CREDIT is a dummy variable indicating household's access to credit where CREDIT $=1$ if anyone in the household has borrowed greater than 150 birr from someone outside the household or from an institution for business or farming purposes over the past 12 months and 0 if otherwise.

LANDHOLDING SIZE stands for size of the land holding of a household measured in meter squared.

OVERALLPLOTOWN is a dummy variable indicating household's plot ownership where OVERALLPLOTOWN

$=1$ if the household has some plot under its ownership (acquired through inheritance or local leaders' grant) and 0 if otherwise.

AVERPLOTSLOPE stands for the average plot slope of a household' overall plot measured in percent. OVERALLFERTILEPLOT is a dummy variable indicating household's overall plot soil quality where OVERALLFERTILEPLOT $=1$ if the household has some plot with fair or good soil quality and 0 if otherwise. DSTNEARMKT stands for distance to the nearest market from residence measured in kilometer.

DSTMAJROAD stands for distance to the nearest major road from residence measured in kilometer.

DSTNEARPOPCENTER stands for distance to the nearest population center with more than 20,000 people from residence measured in kilometer.

OXEN stands for the total number of oxen owned by a household. 
HHTLU stands for the total livestock units currently owned and kept by a household.

EXCONTACT is a dummy variable indicating whether a household had participated in the extension program where EXCONTACT $=1$ if the household had participated in the extension program and 0 if otherwise.

NONAGRIBUSIN is a dummy variable indicating whether a household owned a non-agriculture business or provided a non-agricultural service from home over the past 12 months where NONAGRIBUSIN $=1$ if the household has owned a non-agriculture business or provided a non-agricultural service from home over the past 12 months and 0 if otherwise.

COMIRRIGSCH is a dummy variable indicating presence of an irrigation scheme in the community in which a household reside where COMIRRIGSCH $=1$ if the community in which a household reside has an irrigation scheme and 0 if otherwise.

AMTOFRAIN is a dummy variable indicating the amount of rain received in the last season.

\section{Results and Discussions}

\subsection{Descriptive Statistics}

Various variables that were included in the propensity score matching model that describe the major observed characteristics of the sample respondents are presented in table 1. In Oromia and Benishangul-Gumuz regions, the yield and yield growth of fertilizer adopters is significantly greater than that of non-adopters. Thus, it tentatively shows that there is significant difference in yield and yield growth level in these regions between those households that adopt fertilizer of any kind and those that do not adopt. All the important variables used in the probit model except household's overall plot soil quality have different effect in the different administrative regions considered.

\subsection{Propensity Scores Estimation using Probit Model}

The descriptive statistics has shown a tentative impact of fertilizer adoption on increasing yield in some of the regions. Nevertheless, a mere comparison of yield has no causal meaning since fertilizer adoption is endogenous. And it is difficult to attribute the change to adoption of fertilizer since the difference in yield might be owing to other determinants. To this end, a rigorous impact evaluation method; namely, Propensity Score Matching has to be employed to control for observed characteristics and determine the actual attributable impact of fertilizer adoption on yield growth in different maize producing regions of Ethiopia. Propensity scores for adopters and nonadopters were estimated using a probit model to compare the treatment group with the control group. In this regard, only those significant variables were used in estimating the propensity scores for each region. The check for 'overlap condition' across the treatment and control groups was done and the result as indicated on figure 1 showed that the overlap condition is satisfied for all the five regions considered as there is substantial overlap in the distribution of the propensity scores of both adopters and non-adopters.

For Oromia region, the propensity score for adopters ranges between 0.1672046 and 0.7900534 while it ranges between 0.0571815 and 0.7739796 for non-adopters and the region of common support for the distribution of estimated propensity scores of adopters and non-adopters ranges between 0.1672046 and 0.7900534 . For Amhara region, the propensity score for adopters ranges between 0.2837106 and 0.9383422 while it ranges between 0.1493821 and 0.9496272 for non-adopters and the region of common support for the distribution of estimated propensity scores of adopters and non-adopters ranges between 0.2837106 and 0.9383422 . For SNNP region, the propensity score for adopters ranges between 0.0578879 and 0.8832533 while it ranges between 0.0333115 and 0.7807528 for non-adopters and the region of common support for the distribution of estimated propensity scores of adopters and non-adopters ranges between 0.0578879 and 0.8832533 . For Tigray region, the propensity score for adopters ranges between 0.2292409 and 0.9999998 while it ranges between 0.1964364 and 0.9684217 for non-adopters and the region of common support for the distribution of estimated propensity scores of adopters and non-adopters ranges between 0.2292409 and 0.9999998 . For Benishangul-Gumuz region, the propensity score for adopters ranges between 0.2007994 and 1 while it ranges between $1.21 \mathrm{e}-19$ and 0.7252187 for non-adopters and the region of common support for the distribution of estimated propensity scores of adopters and non-adopters ranges between 0.2007994 and 1 . When matching techniques are employed, observations whose propensity score lies outside this range were discarded.

\subsection{Assessing Matching Quality}

Checking whether the matching procedure is able to balance the distribution of the relevant variables in both the control and treatment group is important in using the propensity score method. The before and after matching covariate balancing tests presented on table 2 suggested that the proposed specification of the propensity score is fairly successful in balancing the distribution of covariates between the two groups as indicated by decreasing pseudo $\mathrm{R}^{2}$ for all regions except Tigray, decreasing mean standardized bias for all regions, the insignificant $\mathrm{p}$ values of the likelihood ratio test for Tigray and Benishangul-Gumuz regions and satisfied interval value of Rubin's R (ratio of treated to (matched) non-treated variances of the propensity score index) after matching for all regions except Tigray and Benishangul-Gumuz. 


\section{Results}

Different matching algorithms are available for Propensity Score Matching with nearest neighbor matching and kernel matching being the most common ones (Kikulwe et al., 2012 citing Caliendo and Kopeinig, 2008). Accordingly, nearest neighbor matching matches adopters with non-adopters with the nearest propensity score, while controlling for differences between adopters and non-adopters whereas kernel matching computes treatment effects by deducting from each outcome observation in the treatment group a weighted average of outcomes in the control group. Table 3 depicts the average impact of fertilizer adoption on maize yield growth using nearest neighbor matching one and five $(\mathrm{NN}=1$ and $\mathrm{NN}=5)$ as well as Epanechnikov kernel matching with two band widths $(\mathrm{BW}=0.03$ and $\mathrm{BW}=0.06)$. Accordingly, all or most of the matching algorithms employed support the hypothesis that fertilizer adoption has a positive and significant impact on yield growth in only two of the five regions considered, namely Tigray and Benishangul-Gumuz. Moreover, fertilizer adoption has a higher impact on yield growth in Tigray region, ranging from $96-116 \%$, compared to that in Benishangul-Gumuz region, ranging from $36-66 \%$.

\section{Conclusion and Recommendation}

This study is undertaken to identify the regional disparity in the impact of adoption of fertilizer on maize yield growth among different major maize producing administrative regions of Ethiopia. It used propensity score matching technique which is a robust impact evaluation technique that identifies the impact which can be attributed to fertilizer adoption. The study also employed and compared various matching algorithms to ensure robustness of the impact estimates. Finally, the study concludes that adoption of fertilizer doesn't have the desired positive and significant impact on yield growth in all of the different major maize producing administrative regions of the country. Moreover, its impact greatly varies among the regions. Therefore, this study recommends that the agricultural research and extension system of the country should be strengthened to further take into account the differences among different regions and areas (like zones, woredas and "kebeles"/villages) havivg high variability in landscape positions, agro-ecologies, soil characteristics and management practices/farming systems in order to generate and scale-up site- and context-specific type and quantity of fertilizer as well as other appropriate improved agricultural technologies and information that suits to the specific conditions of all maize producing farm households of the country.

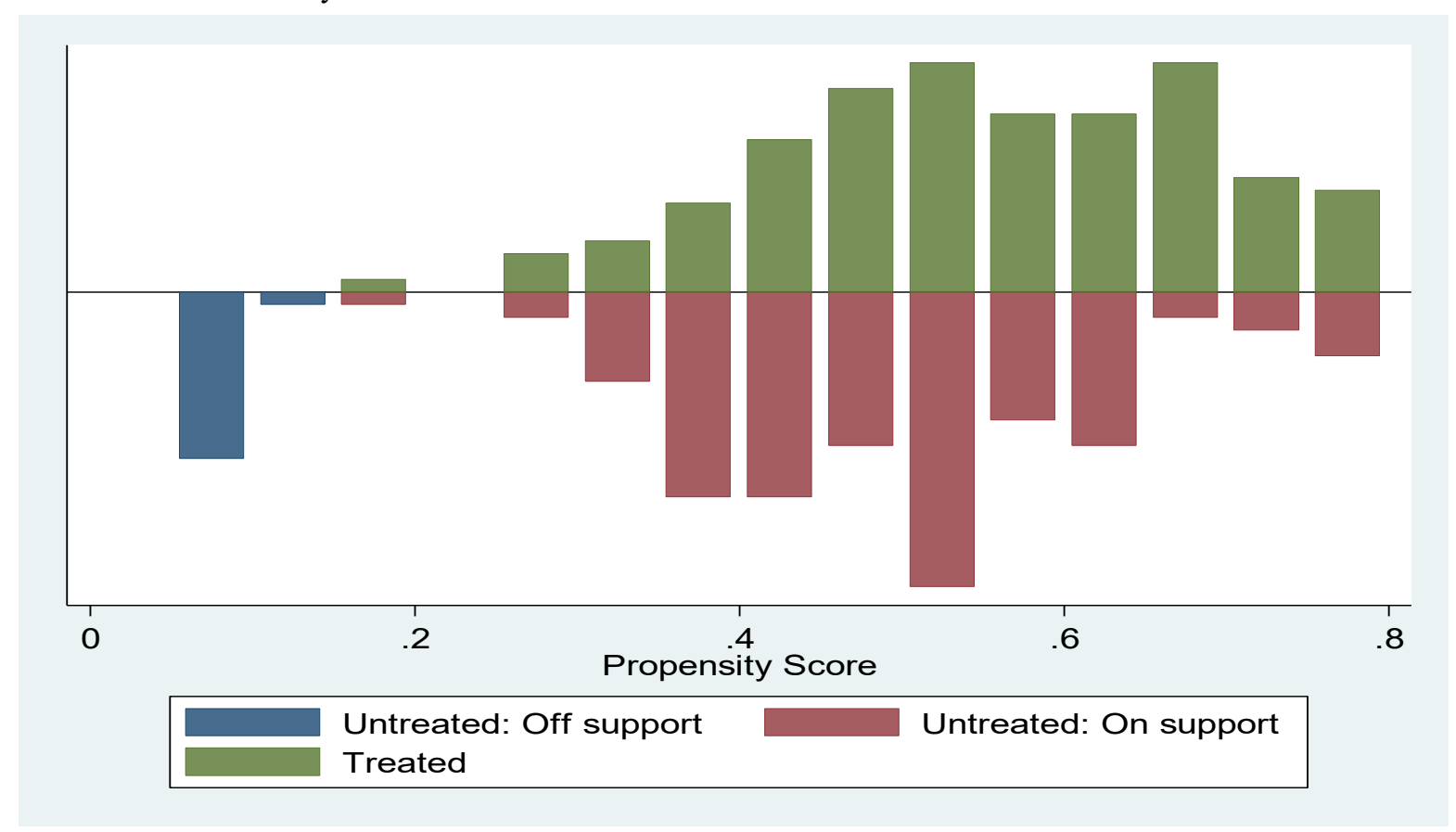

Figure 1(a): Distribution of propensity scores of adopters and non-adopters for Oromia region 


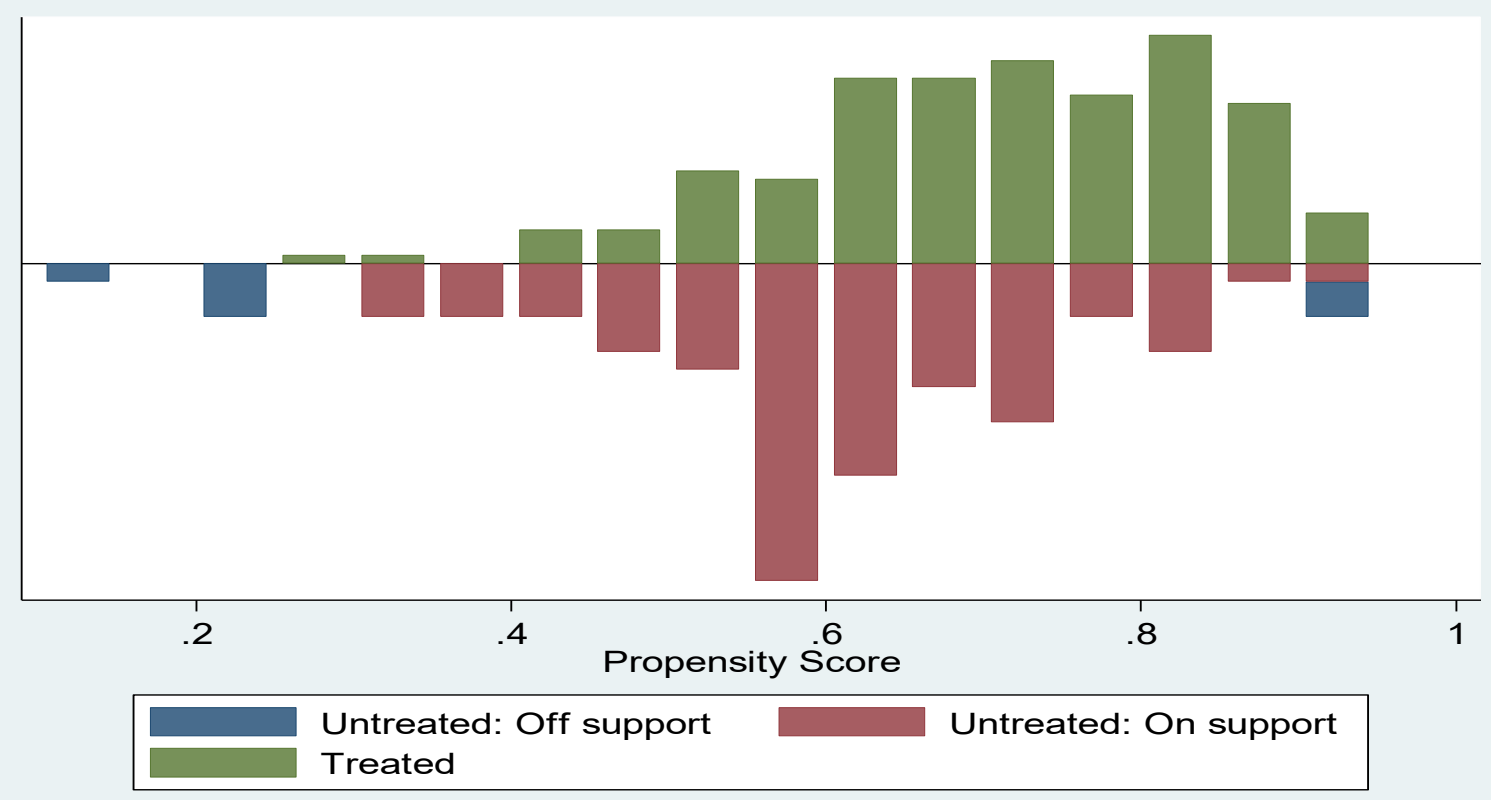

Figure 1(b): Distribution of propensity scores of adopters and non-adopters for Amhara region

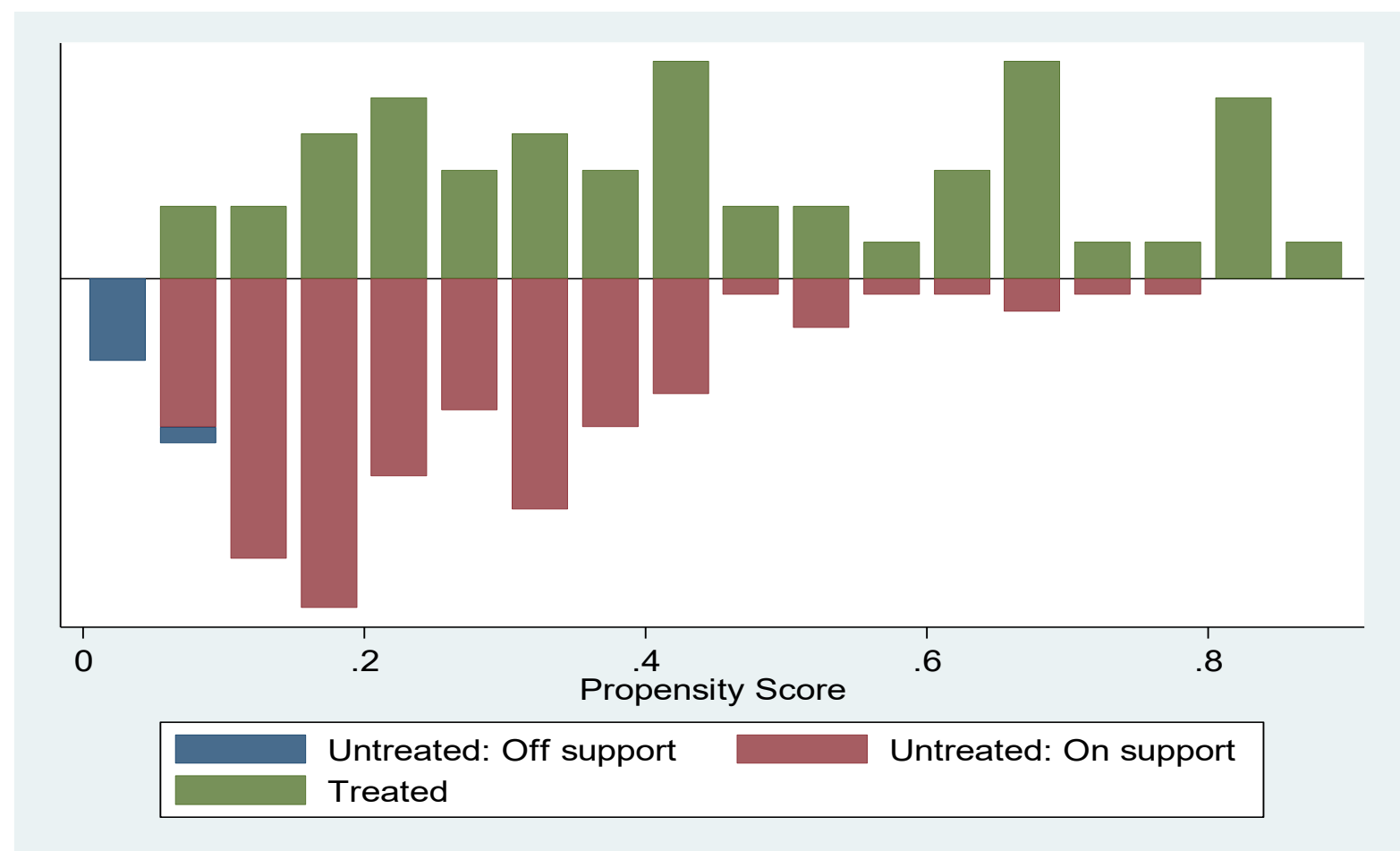

Figure 1(c): Distribution of propensity scores of adopters and non-adopters for SNNP region 


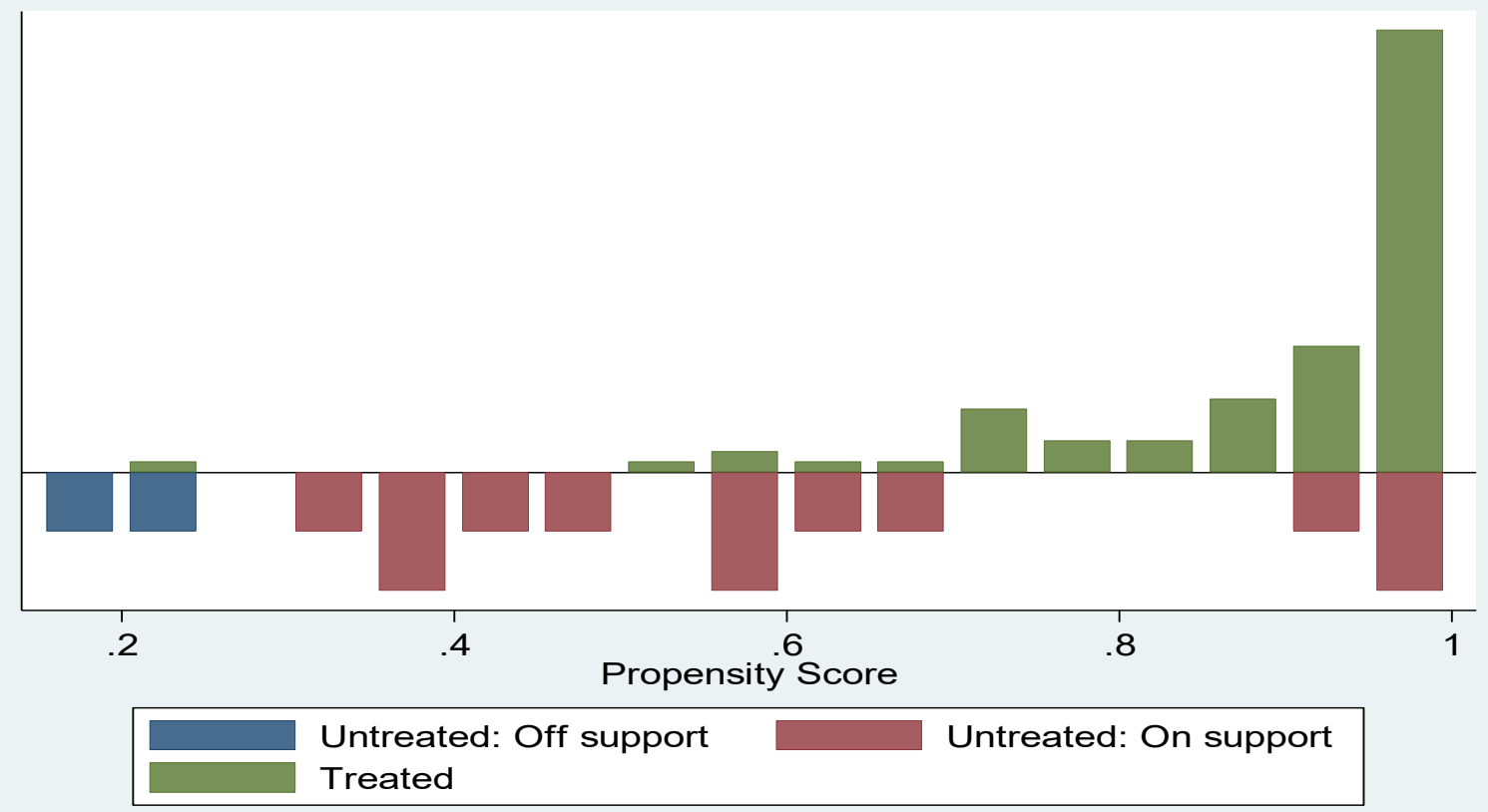

Figure 1(d): Distribution of propensity scores of adopters and non-adopters for Tigray region

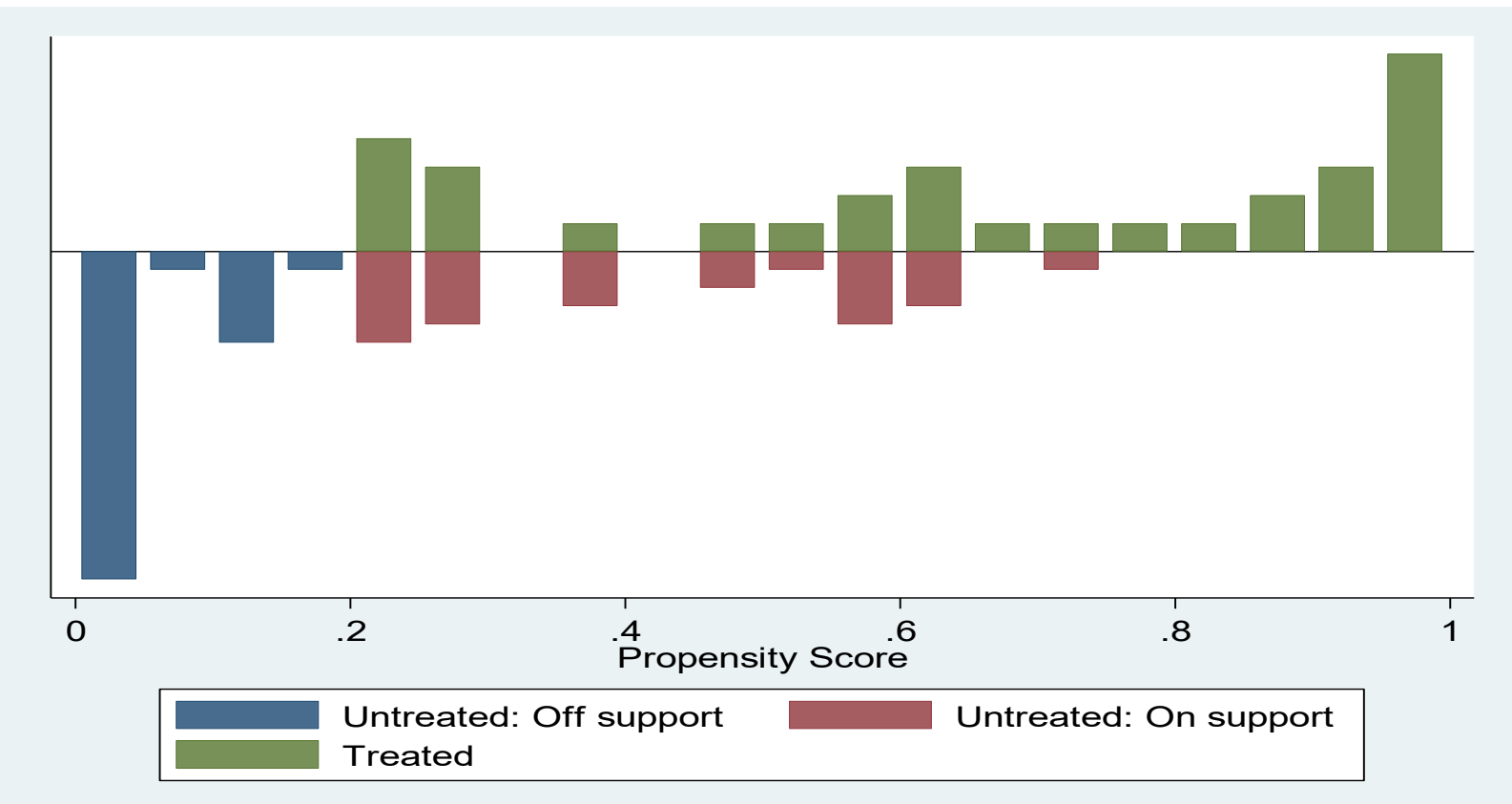

Figure 1(e): Distribution of propensity scores of adopters and non-adopters for Benishangul-Gumuz region 
Table 1: Descriptive statistics of important variables used in the probit model-Propensity Score Matching

\begin{tabular}{|c|c|c|c|c|c|c|c|c|c|c|c|c|c|c|c|c|c|c|c|c|c|}
\hline \multirow[t]{2}{*}{ Variables } & \multirow[t]{2}{*}{ Unit } & \multicolumn{5}{|c|}{ Adopters Mean(se) } & \multicolumn{5}{|c|}{ Non-adopters Mean(se) } & \multicolumn{5}{|c|}{ Aggregate Mean(se) } & \\
\hline & & Oromia & $\begin{array}{l}\text { Ambara } \\
\end{array}$ & Tigray & $\begin{array}{l}\text { South } \\
\text { NNP } \\
\end{array}$ & $\begin{array}{l}\text { Benikas } \\
\text { Cumux } \\
\text { Cumat }\end{array}$ & Oromis & $\begin{array}{l}\text { Ambara } \\
\end{array}$ & Tieray & 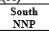 & 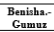 & Oromia & Ambara & Tigray & 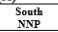 & 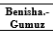 & Oromia & Ambars & Tigray & $\begin{array}{l}\text { South } \\
\text { SNP }\end{array}$ & 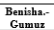 \\
\hline 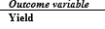 & 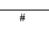 & 28.76 & $\begin{array}{ll}15.60 \\
\end{array}$ & $\overline{16.13}$ & $43(7.98)$ & 46.27 & 21.62 & 19.62 & 12.06 & $\begin{array}{l}98.14 \\
\end{array}$ & 16.599 & 255.41 & 16.75 & ${ }_{15.33}$ & 78.68 & 28.71 & $-1.33^{*}$ & 1.02 & -0.42 & 0.83 & $-1.5: 5 *$ \\
\hline In Yield & $\%$ & 20.02 & $\begin{array}{l}1.40 \\
2.34 \\
0.09\end{array}$ & $\begin{array}{l}4.194 \\
2.19 \\
0.09\end{array}$ & 3.08 & $\begin{array}{ll}1.3 .32 \\
3.15\end{array}$ & $\begin{array}{l}3.201 \\
2.61 \\
0.099\end{array}$ & $\begin{array}{l}5.0 .37 \\
2.37 \\
0.15\end{array}$ & $\begin{array}{l}2.230 \\
2.13 \\
0.19\end{array}$ & $\begin{array}{l}24.937 \\
2.87 \\
0.17\end{array}$ & $\begin{array}{ll}0.397 \\
2.57 \\
0.0710\end{array}$ & 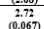 & $\begin{array}{l}1.38 \\
2.35 \\
0.085\end{array}$ & $\begin{array}{l}0.348 \\
2.18 \\
0.08\end{array}$ & $\begin{array}{l}3.934 \\
3.95 \\
0.099\end{array}$ & $2.83(0.1)$ & $-1.55^{*}$ & 0.13 & -0.31 & -1.12 & $-3.52^{1+* *}$ \\
\hline 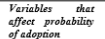 & & & & & & & & & & & & & & & & & & & & & \\
\hline $\begin{array}{l}\text { Fisper } \\
\text { HHACE }\end{array}$ & \# & $\begin{array}{lll}48.72 \\
0.29\end{array}$ & $\begin{array}{lll}4.323 \\
(1.15)\end{array}$ & $\begin{array}{l}50.59 \\
0.30\end{array}$ & $\begin{array}{l}4.19 \\
(1.154)\end{array}$ & $\frac{44,74}{2.24}$ & $\begin{array}{lll}45.19 \\
0.399\end{array}$ & $\begin{array}{ll}51.63 \\
0.62\end{array}$ & $\begin{array}{l}4.5 \\
0.65\end{array}$ & $\begin{array}{l}45.43 \\
(1.2) \\
(1.0\end{array}$ & $\begin{array}{l}46.13 \\
20.17) \\
\end{array}$ & $\begin{array}{l}48.46 \\
(0.5)\end{array}$ & $\begin{array}{l}4.939 \\
(0.94)\end{array}$ & $\begin{array}{lll}49.36 \\
(1.177\end{array}$ & $48(0.98)$ & 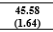 & -0.28 & $1.66 \pm+$ & $2.211+*$ & 0.62 & 0.41 \\
\hline 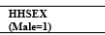 & 1=Yes & $\begin{array}{l}(1.22) \\
(0.037 \\
(0.92\end{array}$ & $\begin{array}{l}(1.18) \\
1.187 \\
(0.03)\end{array}$ & $\begin{array}{l}(1.50) \\
1.037 \\
(0.037\end{array}$ & $\begin{array}{l}\text { (1.54) } \\
(1.024)\end{array}$ & $\begin{array}{l}(1.4) \\
\left(\begin{array}{ll}1.46 \\
(0.07)\end{array}\right.\end{array}$ & $\begin{array}{l}1(1.19) \\
(0.032)\end{array}$ & $\begin{array}{l}\left(\begin{array}{l}1.62) \\
1.21 \\
(0.05)\end{array}\right. \\
\end{array}$ & $\begin{array}{l}(2.53) \\
1.53 \\
(0.093)\end{array}$ & 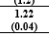 & $\begin{array}{l}(1.11) \\
1.0 .6 \\
0.06\end{array}$ & $\begin{array}{l}(0.9) \\
\text { (1.19) } \\
(0.025)\end{array}$ & $\begin{array}{l}0.9 .19 \\
1.02) \\
(0.02)\end{array}$ & $\begin{array}{l}(1.17) \\
10.030 \\
(0.030\end{array}$ & 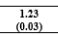 & 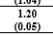 & -1.28 & 0.38 & $3.81^{1+*+4}$ & -0.45 & 0.73 \\
\hline 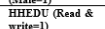 & $1=\mathrm{yes}$ & 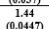 & $\begin{array}{ll}0.06 \\
1.66 \\
0.040\end{array}$ & $\begin{array}{l}0.056 \\
1.565 \\
0.05\end{array}$ & $\begin{array}{l}1.59 \\
1.00 \\
100\end{array}$ & 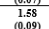 & $\begin{array}{l}1.54 \\
\text { 1.54 } \\
0.045\end{array}$ & $\begin{array}{l}0.097 \\
\text { 1. } 1.75 \\
0.05\end{array}$ & $\begin{array}{l}0.0357 \\
1.567 \\
1009\end{array}$ & $\begin{array}{l}0.047 \\
1.65 \\
0.045\end{array}$ & $\begin{array}{l}0.169 \\
\text { i. } 0.9 \\
0.07\end{array}$ & 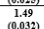 & $\begin{array}{l}0.027 \\
1.70 \\
0.033\end{array}$ & 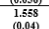 & $\begin{array}{l}1.033 \\
6.03 \\
6.039\end{array}$ & 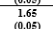 & $1.72^{* *}$ & $1.74^{* \star}$ & 0.11 & 0.86 & 0.96 \\
\hline $\begin{array}{l}\text { HHFELIGION } \\
\text { HHREN }\end{array}$ & $\begin{array}{c}1=0 \text { ron } \\
\text { thodox }\end{array}$ & $\begin{array}{l}0.031 \\
0.31 \\
0.041\end{array}$ & $\begin{array}{ll}0.70 \\
0.703 \\
(0.035\end{array}$ & 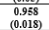 & $\begin{array}{l}0.41 \\
0.41 \\
0.06\end{array}$ & $\begin{array}{ll}0.03 \\
0.03 \\
0.087\end{array}$ & $\begin{array}{l}0.025 \\
0.259 \\
0.039\end{array}$ & $\begin{array}{ll}0.06 \\
0.063) \\
0.035)\end{array}$ & $\begin{array}{l}0.067 \\
0.967 \\
0.033)\end{array}$ & $\begin{array}{l}0.34 \\
0.34 \\
0.04\end{array}$ & $\begin{array}{l}0.018 \\
0.0 .84 \\
0.04\end{array}$ & $\begin{array}{ll}0.028 \\
0.028 \\
0.0238\end{array}$ & $\begin{array}{lll}0.69 \\
0.029\end{array}$ & $\begin{array}{l}0.0 .96 \\
0.0610 \\
0.010\end{array}$ & $\begin{array}{l}0.036 \\
0.036 \\
0.03)\end{array}$ & $\begin{array}{ll}0.0 .9 \\
0.049 \\
0.049\end{array}$ & -0.94 & -0.72 & 0.21 & -1.13 & $-3.11^{* * *+*}$ \\
\hline HHREI & 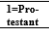 & $\begin{array}{ll}0.31 \\
(0.0411) \\
\end{array}$ & $\begin{array}{lll}0.006 \\
(0.006 \\
(0.060\end{array}$ & $0(0)$ & $\begin{array}{l}0.44 \\
(0.06) \\
\end{array}$ & $\begin{array}{l}0.06 \\
0.045 \\
(0.05\end{array}$ & $\begin{array}{l}0.29 \\
(0.0407 \\
\end{array}$ & $0(0)$ & $0(0)$ & $\begin{array}{l}0.55 \\
0.04) \\
0.04\end{array}$ & $\begin{array}{ll}0.07 \\
0.054) \\
(0.045\end{array}$ & 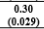 & $\begin{array}{ll}0.004 \\
(0.044) \\
(0.04\end{array}$ & $0(0)$ & $\begin{array}{ll}0.51 \\
0.03) \\
(.03)\end{array}$ & $\begin{array}{ll}0.13 \\
0.038) \\
(0.38\end{array}$ & -0.23 & -0.69 & . & $1.55^{\star}$ & $1.33^{*}$ \\
\hline HHRELIGON & 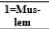 & $\begin{array}{ll}0.35 \\
(0.0420)\end{array}$ & $\begin{array}{l}0.07 \\
(0.034) \\
\end{array}$ & $\begin{array}{ll}0.025 \\
(0.014)\end{array}$ & $\begin{array}{ll}0.11 \\
(0.04)\end{array}$ & $\begin{array}{l}0.08 \\
0.09 \\
0.09\end{array}$ & $\begin{array}{ll}0.0 .37 \\
(0.0433) \\
\end{array}$ & $\begin{array}{l}.0 .033 \\
(0.052) \\
\end{array}$ & $\begin{array}{c}0.033 \\
0.033) \\
\end{array}$ & $0(0)$ & $\begin{array}{l}0.71 \\
0.077\end{array}$ & $\begin{array}{l}0.36 \\
(0.3) \\
(0.3)\end{array}$ & $\begin{array}{ll}0.09 \\
(0.299)\end{array}$ & $\begin{array}{l}0.027 \\
(0.013)\end{array}$ & $\begin{array}{l}0.04 \\
(0.01) \\
(0.1)\end{array}$ & $\begin{array}{l}0.06 \\
0.06 \\
0.05\end{array}$ & 0.31 & 0.92 & 0.24 & $-4.11^{* \star \star *}$ & 1.16 \\
\hline FANIII_SIZE & $\#$ & $\begin{array}{l}5.82 \\
(0.206)\end{array}$ & $\begin{array}{l}4.90 \\
(0.16)\end{array}$ & $\begin{array}{l}5.57 \\
(0.20)\end{array}$ & $\begin{array}{l}5.54 \\
(0.27)\end{array}$ & $\begin{array}{l}5.16 \\
(0.39)\end{array}$ & $\begin{array}{l}5.79 \\
(0.220 \\
-\end{array}$ & $\begin{array}{l}4.73 \\
(0.26) \\
\end{array}$ & $\begin{array}{l}4.27 \\
(0.34)\end{array}$ & $\begin{array}{l}8.87 \\
(0.22)\end{array}$ & $5.27(0.3)$ & $\begin{array}{ll}5.8 .11 \\
(0.153)\end{array}$ & $\begin{array}{l}4.84 \\
(0.13)\end{array}$ & $\begin{array}{l}5.31 \\
(0.18)\end{array}$ & $\begin{array}{l}5.76 \\
(0.17) \\
\end{array}$ & $\begin{array}{l}5.53 \\
(0.24)\end{array}$ & -0.10 & -0.57 & $3.04 * *+2$ & 0.93 & 0.23 \\
\hline CREDIT & 1=yez & & $\begin{array}{l}0.26 \\
(0.03)\end{array}$ & $\begin{array}{l}0.23 \\
(0.04)\end{array}$ & $\begin{array}{l}0.0 .55 \\
(0.055) \\
-10\end{array}$ & $\left.\begin{array}{l}0.032 \\
(0.032)\end{array}\right)$ & $\begin{array}{l}0.13 \\
(0.030)\end{array}$ & $\begin{array}{l}0.06 \\
(0.04)\end{array}$ & $\begin{array}{l}0.13 \\
(0.06)\end{array}$ & $\begin{array}{l}0.17 \\
(0.032)\end{array}$ & $\begin{array}{l}0.042 \\
0.0299 \\
0.029\end{array}$ & $\begin{array}{l}0.17 \\
(0.024)\end{array}$ & $\begin{array}{l}0.22 \\
(0.026 \\
\end{array}$ & $\begin{array}{l}0.21 \\
0.03) \\
0.03\end{array}$ & $\begin{array}{l}0.23 \\
(0.029)\end{array}$ & $\begin{array}{l}0.038 \\
(0.252) \\
(0.25)\end{array}$ & $-1.97+* *+$ & $-1.77^{* *}$ & -1.13 & $-2.89+* *$ & 0.21 \\
\hline $\begin{array}{l}\text { LANDHOLDING } \\
\text { SILE }\end{array}$ & Sq,m & 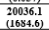 & 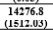 & 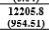 & $\begin{array}{l}118444.1 \\
(2436.4)\end{array}$ & 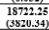 & 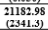 & 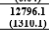 & 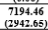 & 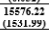 & 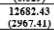 & 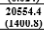 & $\begin{array}{l}13792.24 \\
(1103)^{4}\end{array}$ & 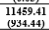 & 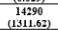 & 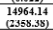 & 0.11 & 0.63 & $2.94 * z$ & $1.36 *$ & 125 \\
\hline $\begin{array}{l}\text { OVERALLPLOT } \\
\text {-OWN }\end{array}$ & l=yes & $\begin{array}{l}0.968) \\
(0.011) \\
(0.01)\end{array}$ & $\begin{array}{l}0.983 \\
(0.010) \\
(0.030\end{array}$ & 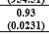 & $\begin{array}{l}(24+0.40) \\
1(0) \\
\end{array}$ & 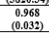 & $\begin{array}{l}0.88 \\
0.029) \\
(0.029)\end{array}$ & $\begin{array}{l}0.90 .13 \\
0.012) \\
(0.012)\end{array}$ & $\begin{array}{l}0.84 .033 \\
(0.0692) \\
(0.032)\end{array}$ & 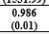 & $\begin{array}{l}0.90 .451 \\
0.989 \\
(0.029)\end{array}$ & $\begin{array}{l}0.940 .3 \\
0.010 \\
(0.010)\end{array}$ & $\begin{array}{l}10.954 \\
0.008) \\
(0.08)\end{array}$ & $\begin{array}{l}0.914) \\
(0.0232)\end{array}$ & $\begin{array}{l}0.91 .021) \\
(0.006) \\
\end{array}$ & $\begin{array}{l}0.53 .52) \\
0.022) \\
(0.022)\end{array}$ & $-3.34+2 * x$ & 0.31 & $-1.73^{* *}$ & -1.03 & -0.21 \\
\hline $\begin{array}{l}\text { AVERPLOTSLO } \\
{ }_{-\mathrm{PE}}\end{array}$ & $\%$ & $\begin{array}{l}1 \begin{array}{l}1.27 \\
(0.65)\end{array} \\
\end{array}$ & $\begin{array}{l}1 \begin{array}{l}1.34 \\
(0.70)\end{array} \\
\text { (a) }\end{array}$ & $\begin{array}{l}1.3 .22 \\
(0.84)\end{array}$ & 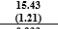 & $\begin{array}{l}6.69 \\
(0.85) \\
(0.5)\end{array}$ & $\begin{array}{l}1.2 .66 \\
(0.74)\end{array}$ & $\begin{array}{l}16.94 \\
(0.99)\end{array}$ & $\begin{array}{l}1.2 .67 \\
(1.68)\end{array}$ & $\begin{array}{l}19.29 \\
0.7\end{array}$ & $\begin{array}{l}\frac{5.577}{(0.31)} \\
(0.30\end{array}$ & $\begin{array}{l}12.37 \\
(0.49)\end{array}$ & $\begin{array}{l}1 \begin{array}{l}1.53 \\
(0.57)\end{array} \\
0\end{array}$ & $\begin{array}{l}1.341 \\
(0.75)\end{array}$ & $\begin{array}{l}\begin{array}{l}18.02 \\
(0.63)\end{array} \\
\end{array}$ & $5.79(0.3)$ & 0.19 & 0.49 & -0.56 & $2.94 * \pi+$ & $-2.17^{* * *}$ \\
\hline $\begin{array}{l}\text { OVERALLLFR- } \\
\text { TILPFLOT }\end{array}$ & l=yes & $\begin{array}{l}0.89 \\
(0.028)\end{array}$ & $\begin{array}{l}0.08 \\
(0.025)\end{array}$ & $\begin{array}{l}0.86 \\
(0.032) \\
\end{array}$ & $\begin{array}{l}\begin{array}{l}0.933 \\
(0.029)\end{array} \\
\text { (a) }\end{array}$ & $\begin{array}{l}0.00 \\
(0.05) \\
\end{array}$ & $\begin{array}{l}0.88 \\
(0.029)\end{array}$ & $\begin{array}{l}0.04 \\
(0.041) \\
(0.0)\end{array}$ & $\begin{array}{l}0.83 \\
(0.071)\end{array}$ & $\begin{array}{l}0.944 \\
(0.19)\end{array}$ & $\begin{array}{l}\frac{0.92}{(0.04)} \\
(0.9)\end{array}$ & 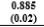 & $\begin{array}{l}0.87 \\
(0.021)\end{array}$ & $\begin{array}{l}0.05 \\
(0.029) \\
(0.02\end{array}$ & $\begin{array}{l}0.94 \\
(0.019\end{array}$ & $\begin{array}{l}0.91 \\
0.033) \\
0.03\end{array}$ & -0.24 & -0.78 & -0.40 & 0.30 & 0.20 \\
\hline $\begin{array}{l}\text { DSTNEARIIKT } \\
\end{array}$ & $\mathrm{km}$ & $\begin{array}{l}0.16 \\
6.16 \\
(3.5\end{array}$ & 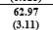 & $\begin{array}{l}6.36 \\
6.356\end{array}$ & $\begin{array}{l}1047 \\
16.57 \\
(6.5)\end{array}$ & $\begin{array}{l}84.39 \\
6.529\end{array}$ & $\begin{array}{l}\frac{8.22}{8.24} \\
(4.8)^{2}\end{array}$ & $\begin{array}{l}54.36 \\
5.325\end{array}$ & $\begin{array}{l}\text { 6.2.27 } \\
4.717\end{array}$ & $\begin{array}{l}133.75 \\
6(5.22)\end{array}$ & $\begin{array}{l}2.3 .99 \\
7.60\end{array}$ & 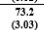 & $\begin{array}{l}60.25 \\
0.45 \\
0.45\end{array}$ & $\begin{array}{l}6.74 .74 \\
60.09\end{array}$ & 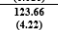 & 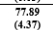 & $3.04+4 t+$ & $-1.61^{*}$ & -0.11 & $3.36+* *$ & -1.2 \\
\hline DSTMAJROAD & $\mathrm{km}$ & $\begin{array}{l}12.42 \\
(1.05\end{array}$ & $\begin{array}{l}24.99 \\
(1.75\end{array}$ & $\begin{array}{l}22.03 \\
(10.62)\end{array}$ & 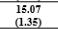 & $\begin{array}{l}12.55 \\
(2.27) \\
\end{array}$ & $\begin{array}{l}1.29 \\
(1.19 \\
(0.15\end{array}$ & $\begin{array}{l}20.34 \\
20.20) \\
(0.20\end{array}$ & $29.2(4.1)$ & $\begin{array}{l}15.63 \\
0.16)\end{array}$ & $\begin{array}{l}25.65 \\
20.19 \\
0.19\end{array}$ & $\begin{array}{l}12.36 \\
(0.86) \\
(0.8)\end{array}$ & $\begin{array}{l}23.49 \\
(1.38) \\
(1.8)\end{array}$ & $\begin{array}{ll}23.48 \\
(1.55)\end{array}$ & $\begin{array}{l}15.43 \\
15.099 \\
\end{array}$ & $\begin{array}{l}20.51 \\
1.55 \\
0.55\end{array}$ & -0.09 & $-1.57 *$ & $1.877 *$ & 0.30 & $3.7^{2}+*+2$ \\
\hline $\begin{array}{l}\text { DSTNEARPOP- } \\
\text { CENTER }\end{array}$ & $\mathrm{km}$ & $\begin{array}{l}38.98 \\
(2.2) \\
\end{array}$ & $\begin{array}{l}\begin{array}{l}4.24 \\
(2.48)\end{array} \\
\end{array}$ & $\begin{array}{l}7.17 \\
(2.14) \\
\end{array}$ & $\begin{array}{l}33.61 \\
(1.77)\end{array}$ & $\begin{array}{l}83.37 \\
(6.72) \\
\end{array}$ & $\begin{array}{l}51.23 \\
(2.7) \\
\end{array}$ & $\begin{array}{l}42.60 \\
(2.79) \\
(2.79)\end{array}$ & $\begin{array}{l}47.97 \\
(4.98) \\
\end{array}$ & $\begin{array}{l}4.32 \\
(1.64) \\
(1.64)\end{array}$ & $\begin{array}{l}7.7 .15 \\
(5.65) \\
(5.5)\end{array}$ & $\begin{array}{l}45.10 \\
1.81 \\
1.8\end{array}$ & $\begin{array}{l}\begin{array}{c}4.35 \\
(1.90 \\
(1.90\end{array} \\
\end{array}$ & $\begin{array}{l}43.34 \\
(1.98) \\
\end{array}$ & $\begin{array}{l}39.3 \\
(1.26) \\
\end{array}$ & $\begin{array}{l}7735 \\
(43)\end{array}$ & $3.52^{*+*}$ & 0.09 & 1.18 & $3.37 * * *$ & -122 \\
\hline OXEN & $*$ & $\begin{array}{l}1.44 \\
(0.12)\end{array}$ & $\begin{array}{l}1.37 \\
(0.09)\end{array}$ & $\begin{array}{l}1.45 \\
(0.09)\end{array}$ & $\begin{array}{l}1.12 \\
(0.14)\end{array}$ & $\begin{array}{l}0.77 \\
(0.21)\end{array}$ & $\begin{array}{l}1.25 \\
(0.11) \\
(0.0)\end{array}$ & $\begin{array}{l}1.18 \\
(0.14) \\
(0.10\end{array}$ & $\begin{array}{l}0.47 \\
(0.16)\end{array}$ & $\begin{array}{l}1.48 \\
(0.15) \\
(0.00\end{array}$ & 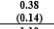 & $\begin{array}{l}1.34 \\
(0.08)\end{array}$ & $\begin{array}{l}1.31 \\
(0.07) \\
\end{array}$ & $\begin{array}{l}1.26 \\
(0.08)\end{array}$ & 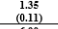 & $\begin{array}{l}0.03 \\
0.122\end{array}$ & -1.18 & -1.16 & $.5 .12^{2+* t}$ & $1.56^{\star}$ & $-1.67 * *$ \\
\hline HHTLU & \# & $\begin{array}{l}4.61 \\
(0.35) \\
\end{array}$ & $\begin{array}{l}4.46 \\
(0.34) \\
(0.5)\end{array}$ & $\begin{array}{l}4.48 \\
(0.44)\end{array}$ & $\begin{array}{l}\begin{array}{l}4.08 \\
(0.44)\end{array} \\
\end{array}$ & $\begin{array}{l}2.29 \\
(0.517) \\
(0.517\end{array}$ & $\begin{array}{l}4.83 \\
(0.41) \\
\end{array}$ & $\begin{array}{l}3.44 \\
(0.35) \\
\end{array}$ & $\begin{array}{l}1.79 \\
0.57) \\
0\end{array}$ & $\begin{array}{l}8.52 \\
(3.76) \\
\end{array}$ & $\begin{array}{l}1.19 \\
(0.272)\end{array}$ & 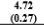 & 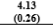 & $\begin{array}{l}4.26 \\
(0.38) \\
(0.9)\end{array}$ & (6.997) & 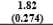 & 0.40 & $-1.86 * *$ & $.337+* t+2$ & 0.85 & $-2.098+* t$ \\
\hline EXCONTACT & $1=$ yez & $\begin{array}{l}0.48 \\
0.045 \\
0.045\end{array}$ & $\begin{array}{l}0.43 \\
\text { (0.338) }\end{array}$ & $\begin{array}{l}0.08 \\
0.043) \\
0.08\end{array}$ & $\begin{array}{l}0.41 \\
0.060\end{array}$ & $\begin{array}{l}0.13 \\
0.06\end{array}$ & $\begin{array}{l}0.29 \\
0.040 \\
0.040\end{array}$ & $\begin{array}{l}0.24 \\
0.05\end{array}$ & $\begin{array}{l}0.3 \\
0.085\end{array}$ & $\begin{array}{l}0.35 \\
0.04 \\
0.04\end{array}$ & $\begin{array}{l}0.06 \\
0.064 \\
0.04)\end{array}$ & $\begin{array}{l}0.38 \\
0.031) \\
(0.31)\end{array}$ & $\begin{array}{l}0.37 \\
0.370 \\
(0.30)\end{array}$ & $\begin{array}{l}0.60 \\
0.04)\end{array}$ & $\begin{array}{l}0.37 \\
(0.3) \\
(0.3)\end{array}$ & $\begin{array}{l}0.09 \\
0.093\end{array}$ & $-3.24^{4+2+x}$ & $-2.91^{1+*+}$ & $3.98+2+x$ & -0.92 & -1.01 \\
\hline $\begin{array}{ll}\text { NONAGRIBUSI } \\
\text { N }\end{array}$ & $1=y$ & $\begin{array}{l}1.93 \\
(0.23) \\
\end{array}$ & $\begin{array}{l}1.97 \\
(0.014) \\
\end{array}$ & $\begin{array}{l}1.97 \\
(0.160) \\
\end{array}$ & 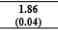 & $\begin{array}{l}1.97 \\
0.013 \\
0.03\end{array}$ & $\begin{array}{l}1.199 \\
(0.028 \\
\end{array}$ & $\begin{array}{c}1.08 \\
0.030 \\
0.030\end{array}$ & $\begin{array}{l}1.9 \\
(0.05877 \\
\end{array}$ & $\begin{array}{l}1.95 \\
(0.199) \\
\end{array}$ & 2 (1) & $\begin{array}{l}1.91 \\
(0.018) \\
\end{array}$ & $\begin{array}{l}1.94 \\
(0.015) \\
\end{array}$ & $\begin{array}{l}1.95 \\
(0.0174) \\
\end{array}$ & $\begin{array}{l}1.92 \\
(0.019) \\
\text { (1) }\end{array}$ & $\begin{array}{l}1.99 \\
(0.011)\end{array}$ & -1.09 & $-2.70^{* * * i z}$ & $-1.54^{*}$ & $2.19 * *$ & 1.25 \\
\hline COMIRRIGSCH & 1-yas & $\begin{array}{l}1.36 \\
(0.043) \\
\end{array}$ & $\begin{array}{l}1.23 \\
(0.032)\end{array}$ & $\begin{array}{l}1.08 \\
(0.024)\end{array}$ & $1.5(0.06)$ & $\begin{array}{l}1.133 \\
(0.08) \\
\end{array}$ & $\begin{array}{l}1.166 \\
(0.045)\end{array}$ & $\begin{array}{l}1.18 \\
(0.043) \\
(0.18\end{array}$ & $\begin{array}{l}1.03 \\
(0.033) \\
\end{array}$ & $\begin{array}{l}1744 \\
(0.05)\end{array}$ & $\begin{array}{l}\frac{1.100}{0.077} \\
0.07\end{array}$ & $\begin{array}{l}1.41 \\
(0.031) \\
\end{array}$ & $\begin{array}{l}1.22 \\
(0.026 \\
\end{array}$ & $\begin{array}{l}1.07 \\
(10.021)\end{array}$ & $\begin{array}{l}1.1 .84 \\
(0.04)\end{array}$ & 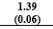 & $1.67^{* *}$ & -0.90 & -0.82 & -0.35 & $2 . .60+ \pm z$ \\
\hline AMTOFRAIN & 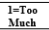 & 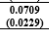 & $\begin{array}{l}0.13 \\
0.020 \\
(0.20\end{array}$ & 0 (0) & $\begin{array}{c}0.008 \\
(0.032) \\
\end{array}$ & $\begin{array}{l}0.03 \\
0.0877 \\
0.057\end{array}$ & $\begin{array}{l}0.0714 \\
(0.2023)\end{array}$ & $\begin{array}{l}0.04 \\
0.041) \\
(0.012)\end{array}$ & $0(0)$ & $\begin{array}{c}0.19 \\
0.033) \\
(0.93)\end{array}$ & $\begin{array}{l}0.17 \\
(0.054)\end{array}$ & $\begin{array}{l}0.0711 \\
0.0 .0162) \\
0.07\end{array}$ & $\begin{array}{l}0.10 \\
(0.109) \\
(0.09\end{array}$ & $\theta(0)$ & $\begin{array}{l}0.15 \\
(0.024)\end{array}$ & $\begin{array}{l}0.24 \\
(0.48) \\
(0.48)\end{array}$ & 0.02 & $-2.41^{* * *+}$ & . & $2.14^{* *}$ & $-1.93 * *+$ \\
\hline AMTOFRAIN & 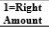 & $\begin{array}{l}0.38 \\
0.038 \\
(0.43)\end{array}$ & $\begin{array}{l}0.060 \\
\text { o.16 } \\
0.0288\end{array}$ & $\begin{array}{l}0.05 \\
0.02)\end{array}$ & $\begin{array}{l}0.21 \\
(0.048) \\
(0.04\end{array}$ & $\begin{array}{l}0.42 \\
0.099 \\
\end{array}$ & $\begin{array}{l}0.30 \\
\text { (0.0.01) }\end{array}$ & $\begin{array}{l}0.11 \\
0.0135 \\
0.0 .03\end{array}$ & $\begin{array}{l}0.033 \\
0.033) \\
(0.03\end{array}$ & $\begin{array}{l}0.077 \\
0.037 \\
0.037\end{array}$ & $\begin{array}{l}0.08 \\
0.0 .87 \\
0.07\end{array}$ & $\begin{array}{l}0.0 .34 \\
0.34 \\
0.37\end{array}$ & $\begin{array}{l}0.14 \\
0.14 \\
0.232\end{array}$ & $\begin{array}{l}0.047 \\
0.017\end{array}$ & $\begin{array}{l}0.25 \\
(0.029) \\
\end{array}$ & 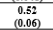 & -1.28 & -1.01 & -0.39 & 0.85 & $1,42^{*}$ \\
\hline AMTOFRAIN & 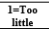 & $\begin{array}{l}0.54 \\
0.044 \\
(0.04\end{array}$ & $\begin{array}{l}0.71 \\
0.03 \\
0.03\end{array}$ & $\begin{array}{l}0.95 \\
0.025\end{array}$ & $\begin{array}{l}0.67 \\
0.05\end{array}$ & $\begin{array}{l}.23 \\
0.08 \\
(0.08)\end{array}$ & $\begin{array}{l}0.02 \\
(0.023) \\
(0.02\end{array}$ & $\begin{array}{l}0.85 \\
0.04 \\
(0.04)\end{array}$ & $\begin{array}{c}0.967 \\
0.033) \\
0.033\end{array}$ & $\begin{array}{l}0.41 \\
0.04 \\
0.04\end{array}$ & $\begin{array}{l}0.025 \\
0.060\end{array}$ & $\begin{array}{l}0.68 \\
0.0311 \\
(0.031\end{array}$ & $\begin{array}{l}0.76 \\
(0.277 \\
(0.27\end{array}$ & $\begin{array}{l}0.933 \\
0.017\end{array}$ & $0.5(0.03)$ & $\begin{array}{l}0.24 \\
0.24 \\
0.055\end{array}$ & $1.35^{*}$ & $2.53 * * t$ & 0.39 & $-3.66+2+1$ & 0.24 \\
\hline
\end{tabular}
***, **, * indicate significance at at $1 \%, 5 \% \& 10 \%$ level respectively.

Source: Own computation, 2020

Table 2: Propensity Score Matching Quality Test

\begin{tabular}{|c|c|c|c|c|c|c|c|c|}
\hline Region & Sample & Ps R2 & LR chi2 & p>chi2 & MeanBias & MedBias & $\mathbf{R}$ & $\% \operatorname{Var}$ \\
\hline \multirow[b]{2}{*}{ Oromia } & Unmatched & 0.082 & 27.93 & 0.000 & 30.8 & 29.6 & $0.42 *$ & 25 \\
\hline & Matched & 0.023 & 7.01 & 0.428 & 11.4 & 10.6 & 0.99 & 0 \\
\hline \multirow[b]{2}{*}{ Amhara } & Unmatched & 0.087 & 27.85 & 0.002 & 28.3 & 28.4 & 0.66 & 33 \\
\hline & Matched & 0.031 & 11.30 & 0.335 & 12.7 & 11.5 & 1.06 & 17 \\
\hline \multirow[b]{2}{*}{ SNNP } & Unmatched & 0.161 & 32.53 & 0.000 & 39.8 & 39.7 & 1.61 & 67 \\
\hline & Matched & 0.095 & 13.23 & 0.211 & 16.7 & 12.9 & 1.40 & 0 \\
\hline \multirow{2}{*}{ Tigray } & Unmatched & 0.346 & 27.24 & 0.001 & 64.2 & 68.6 & 1.16 & 38 \\
\hline & Matched & 0.476 & 91.74 & 0.000 & 49.0 & 30.2 & $2.83 *$ & 50 \\
\hline \multirow{2}{*}{$\begin{array}{c}\text { Benishangul- } \\
\text { Gumuz }\end{array}$} & Unmatched & 0.412 & 43.62 & 0.000 & 54.7 & 48.0 & $0.47^{*}$ & 20 \\
\hline & Matched & 0.265 & 22.79 & 0.007 & 38.0 & 36.6 & $10.25^{*}$ & 20 \\
\hline
\end{tabular}

* if $\mathrm{B}>25 \%, \mathrm{R}$ outside $[0.5 ; 2]$ 
Table 3: Average Treatment Effects estimation using different propensity score matching estimators

\begin{tabular}{|c|c|c|c|}
\hline Region & $\begin{array}{l}\text { Outcome } \\
\text { Variable }\end{array}$ & $\begin{array}{l}\text { Matching } \\
\text { Algorithm }\end{array}$ & ATT (Std. Err.) \\
\hline \multirow{4}{*}{ Oromia } & \multirow{4}{*}{ LnYield } & Nearest Neighbor $(\mathrm{NN}=1)$ & $0.344 * *(0.183)$ \\
\hline & & Nearest Neighbor $(\mathrm{NN}=5)$ & $0.176(0.152)$ \\
\hline & & Kernel $(\mathrm{BW}=0.03)$ & $0.295 * *(0.169)$ \\
\hline & & Kernel $(\mathrm{BW}=0.06)$ & $0.151(0.164)$ \\
\hline \multirow{4}{*}{ Amhara } & \multirow{4}{*}{ LnYield } & Nearest Neighbor $(\mathrm{NN}=1)$ & $0.207(0.258)$ \\
\hline & & Nearest Neighbor $(\mathrm{NN}=5)$ & $0.201(0.211)$ \\
\hline & & Kernel $(\mathrm{BW}=0.03)$ & $0.179(0.174)$ \\
\hline & & Kernel $(\mathrm{BW}=0.06)$ & $0.134(0.195)$ \\
\hline \multirow{4}{*}{ SNNP } & \multirow{4}{*}{ LnYield } & Nearest Neighbor $(\mathrm{NN}=1)$ & $0.521 *(0.330)$ \\
\hline & & Nearest Neighbor $(\mathrm{NN}=5)$ & $0.160(0.285)$ \\
\hline & & Kernel $(\mathrm{BW}=0.03)$ & $0.290(0.255)$ \\
\hline & & Kernel $(\mathrm{BW}=0.06)$ & $0.257(0.251)$ \\
\hline \multirow{4}{*}{ Tigray } & \multirow{4}{*}{ LnYield } & Nearest Neighbor $(\mathrm{NN}=1)$ & $0.962 *(0.630)$ \\
\hline & & Nearest Neighbor $(\mathrm{NN}=5)$ & $0.286(0.480)$ \\
\hline & & Kernel $(\mathrm{BW}=0.03)$ & $1.159 * * *(0.383)$ \\
\hline & & Kernel $(\mathrm{BW}=0.06)$ & $1.060 * * *(0.442)$ \\
\hline \multirow{4}{*}{ Benishangul-Gumuz } & \multirow{4}{*}{ LnYield } & Nearest Neighbor $(\mathrm{NN}=1)$ & $0.658 * *(0.324)$ \\
\hline & & Nearest Neighbor $(\mathrm{NN}=5)$ & $0.575 * * *(0.231)$ \\
\hline & & Kernel $(\mathrm{BW}=0.03)$ & $0.364 *(0.266)$ \\
\hline & & Kernel $(\mathrm{BW}=0.06)$ & $0.433 * *(0.219)$ \\
\hline
\end{tabular}

$* * *, * *, *$ indicate significance at $1 \%, 5 \% \& 10 \%$ level respectively and bootstrapped standard errors are based on 100 replications.

Source: Own computation, 2020

\section{References}

Abate T. , Shiferaw B., Menkir A., Wegary D. , Kebede Y., Tesfaye K., Kassie M., Bogale G., Tadesse B. and Keno T. (2015), "Factors That Transformed Maize Productivity in Ethiopia", Food Sec. (2015) 7:965-981.

Abegaz G. (2011), "Cereal Productivity in Ethiopia: An Analysis Based on ERHS Data", Ethiopian Journal of Economics, Vol. XX, No. 2, October 2011.

Admassie A. and Ayele G. (2004), "Adoption of Improved Technology in Ethiopia”, Ethiopian Development Research Institute (EDRI), Research Report 3.

Bekabil, U.T. (2018), "Review of Challenges and Prospects of Agricultural Production and Productivity in Ethiopia", Journal of Natural Sciences Research, Vol.4, No.18, 2014.

Caliendo M. and Kopeinig S. (2008), "Some Practical Guidance for the Implementation of Propensity Score Matching”, Journal of Economic Surveys (2008) Vol. 22, No. 1, pp. 31-72.

Central Statistical Agency of Ethiopia (CSA), "Ethiopia Socioeconomic Survey, Wave 3 (ESS3) 2015-2016", Public Use Dataset. Ref: ETH_2015_ESS_v02_M. Downloaded from https://microdata.worldbank.org/index.php/catalog/2783/download/41756 on 9/17/2019.

Daniel F. (2018), "Impact of Improved Wheat Varieties Adoption on Productivity: Ethiopia", LAP LAMBERT Academic Publishing, Beau Bassin. ISBN: 978-613-7-42438-4.

Daniel F. and Belay B. (2018). "Impact of Improved Wheat Varieties \& Information's Adoption on Productivity in Ethiopia”, GRIN Publishing, Munich. ISBN: 9783668808096.

Dorosh, P.A. and Rashid, S. (2012), "Food and Agriculture in Ethiopia: Progress and Policy Challenges", University of Pennsylvania Press, Philadelphia, Pennsylvania 19104-4112.

Gebre-Selassie A. and Bekele T., "A Review of Ethiopian Agriculture: Roles, Policy and Small-scale Farming Systems", Global Growing Casebook.

Gebru A. (2006), "The Determinants of Modern Agricultural Inputs Adoption and Their Productivity in Ethiopia (The Case of Amhara and Tigray Regions) ", A Thesis Submitted to the School of Graduate Studies of Addis Ababa University in Partial Fulfillment of the Requirements for the Degree of Master of Science in Economics (Economic Policy Analysis), July, 2006.

Heinrich C., Maffioli A. and Vázquez G. (2010), “A Primer for Applying Propensity-Score Matching”, ImpactEvaluation Guidelines Technical Notes No. IDB-TN-161, Inter-American Development Bank (IDB).

Jaleta, M., Kassie, M. and Marenya, P. (2015), "Impact of Improved Maize Variety Adoption on Household Food Security in Ethiopia: An Endogenous Switching Regression Approach", International Conference of 
Agricultural Economists.

Kelemu, K. (2017), "Determinants of Farmers Access to Information about Improved Wheat Varieties: Case of Farmers in Major Wheat Growing Regions of Ethiopia”, International Journal of Research in Agricultural Sciences, Vol.4, Issue 1.

Kikulwe E.M., Kabunga N.S., Qaim M. (2012), "Impact of Tissue Culture Banana Technology in Kenya: A Difference-In-Difference Estimation Approach”, Courant Research Centre 'Poverty, Equity and Growth in Developing and Transition Countries: Statistical Methods and Empirical Analysis’ Georg-August-Universität Göttingen Discussion Papers No. 117, 37073 Goettingen, Germany.

Lopez-A., D., Husain, S., Bhatia, R., Nath, M. and Vinaygyam, R.M. (2017), "Agricultural Innovation: An Evidence Gap Map”, Evidence Gap Map Report 12, International Initiative for Impact Evaluation (3ie).

MoFED. (2003), "Rural Development Policy and Strategies", Economic Policy and Planning, Ministry of Finance and Economic Development, Addis Ababa.

Olmos A. (2015), “Propensity Scores: A Practical Introduction Using R”, Journal of Multi-Disciplinary Evaluation, Vol. 11, Issue 25.

Welteji, D. (2018), "A Critical Review of Rural Development Policy of Ethiopia: Access, Utilization and Coverage", Agriculture \& Food Security. 